\author{
Mgr Wanda KARPIŃSKA-MIZIELIŃSKA \\ Instytut Badań Rynku, Konsumpcji i Koniunktur - PIB \\ e-mail: wmizielinska@gmail.com
}

\author{
Dr Tadeusz SMUGA, prof. IBRKK-PIB \\ Instytut Badań Rynku, Konsumpcji i Koniunktur - PIB \\ e-mail: tsmuga@interia.pl
}

DOI: $10.15290 /$ oes.2018.04.94.10

\title{
POLSCY EKONOMIŚCI AKADEMICCY OKRESU TRANSFORMACJI. KILKA REFLEKSJI NA TLE WYNIKÓW BADAŃ
}

\begin{abstract}
Streszczenie
Zmiana systemu w Polsce u progu lat dziewięćdziesiątych sprawiła, że podobnie jak inne dziedziny życia społecznego i gospodarczego, ekonomia akademicka podlegała głębokiej transformacji. Wiązało się to ze zmianą dotychczasowego sposobu analizy zjawisk gospodarczych, a także z poszukiwaniem nowych podejść teoretycznych. Wyrazem tego było przede wszystkim odejście od teorii marksistowskiej i asymilacja tradycji neoklasycznej oraz keynesowskiej. Znalazło to również odzwierciedlenie w programach nauczania ekonomii.

Celem arykułu jest spojrzenie na środowisko polskich ekonomistów akademickich w kontekście ich wyborów teoretycznych. Podstawą formułowanych refleksji są wyniki badań przeprowadzonych w ramach projektu badawczego nt. „Identyfikacja polskich ekonomistów ze szkołami myśli ekonomicznej” zrealizowanego w latach 2014-2016 w Instytucie Badań Runku Konsumpcji i Koniunktur-PIB oraz studia literaturowe. Na szerszą charakterystykę środowiska naukowego ekonomistów pozwalają zebrane podczas realizacji projektu dane na temat ich wyborów teoretycznych, poglądów na temat stanu nauk ekonomicznych, barier występujących w rozwoju polskiej ekonomii, a także cech osobowych.

Badania potwierdziły, że istotnymi zmiennymi różnicującymi dokonywane przez ekonomistów wybory szkół myśli ekonomicznych są płeć i wiek. W kontekście dalszego rozwoju polskiej ekonomii akademickiej szczególną uwagę zwrócono na poglądy ekonomistów w wieku 36-45 lat, gdyż w następnych latach będą oni w decydującym stopniu wpływać na treści przekazywane w ramach nauczania ekonomii na wyższych uczelniach. Dokonywane przez nich wybory teoretyczne wskazuja, że nowa ekonomia instytucjonalna może stracić na znaczeniu, a w kwestiach preferowanych rozwiązań polityki gospodarczej przeważać będa poglądy ortodoksyjnych szkół myśli ekonomicznej. Wskazuje to na utrwalenie się przewagi orientacji liberalnej w polskiej ekonomii w najbliższych latach.
\end{abstract}

Słowa kluczowe: szkoły myśli ekonomicznej, ekonomiści akademiccy, ekonomia w Polsce, samoświadomość naukowa, badania empiryczne 


\title{
POLISH ACADEMIC ECONOMISTS OF THE TRANSFORMATION PERIOD. A FEW REFLECTIONS ON THE BASIS OF THE TEST RESULTS
}

\begin{abstract}
Summary
The change of the system in Poland in the early 1990s meant that, like other areas of social and economic life, academic economics was subject to the profound transformation. It was connected with the change of the existing method of analyzing economic phenomena, as well as with the search for new theoretical approaches. The expression of this was, above all, the departure from Marxist theory and the assimilation of the neoclassical and Keynesian tradition. This was also reflected in the economic programs.

The aim of the article is to take a look at the environment of Polish academic economists in the context of their theoretical choices. The basis of the formulated reflections are the results of research carried out as a part of the research project "Identifying Polish economists with schools of economic thought" conducted in 2014-2016 at the Institute of Consumption and Research of Business Cycles and research on PIB and literature studies. The broad characteristics of the scientific community of economists is enabled by the data collected during the project implementation on their theoretical choices, views on the state of economic sciences, barriers to the development of the Polish economy, as well as personal characteristics.

Studies have confirmed that sex and age are important variables that differentiate economic school choices made by economists. In the context of the further development of the Polish academic economy, particular attention was paid to the views of economists aged 36-45, because they will have a decisive influence on the content transferred within the framework of teaching economics at universities in the following years. Their theoretical choices indicate that the new institutional economy may lose its importance, and the views of the orthodox schools of economic thought will dominate reagrding the preferred solutions of economic policy. This indicates the strengthening of the advantage of liberal orientation in the Polish economy in the coming years.
\end{abstract}

Key words: schools of economic thought, academic economists, economics in Poland, scientific selfawareness, empirical research

JEL classification: A14, B41, B50

\section{Wstęp}

Zmiana systemu ekonomicznego w Polsce u progu lat dziewięćdziesiątych XX wieku sprawiła, że podobnie jak inne dziedziny życia społecznego i gospodarczego, również ekonomia akademicka podlegała głębokiej transformacji. W jej przypadku oznaczało to generalną zmianę sposobu analizy zjawisk gospodarczych, w tym poszukiwanie nowych podejść teoretycznych ${ }^{1}$. Wyrazem tego było przede

1 Do połowy lat pięćdziesiątych XX wieku cechą nauczania ekonomii był odwrót od światowej teorii ekonomii i odrzucenie koncepcji i szkół ekonomicznych, które nie wywodziły się z ekonomii marksistowskiej w wersji rozwijanej wówczas w Związku Radzieckim. Od drugiej połowy lat pięćdziesiątych XX wieku, ekonomia marksistowska w Polsce rozwijała się samoistnie, odchodząc 
wszystkim odejście od teorii marksistowskiej i asymilacja tradycji neoklasycznej oraz keynesowskiej. Począwszy od 1990 r. także sytuacja w nauczaniu ekonomii uległa radykalnej zmianie - w programach nauczania ekonomia polityczna socjalizmu i kapitalizmu została zastapiona mikro i makroekonomią wykładana w oparciu o teorie neoklasyczne i keynesowskie².

Zmianom w orientacjach teoretycznych ekonomistów w tym okresie towarzyszyły zjawiska zwiazzane $\mathrm{z}$ procesami globalizacji, upowszechnieniem technologii informacyjnych i uzyskaniem szerokiego dostępu do badań międzynarodowych, a także przekształceniami zachodzącymi w strukturze i funkcjonowaniu uczelni wyż$\mathrm{szych}^{3}$. Tak wielopłaszczyznowa transformacja wywołała wiele zmian w podejściu naukowców do uprawiania swojej dziedziny wiedzy oraz w sposobach analizy badanych zjawisk. Ich efektem było głównie odrzucanie starych i przyjmowanie nowych podejść teoretycznych, zwłaszcza w warunkach postępującej internacjonalizacji badań naukowych.

Skala zmian jakie zachodziły w okresie transformacji systemowej w polskiej ekonomii rodzi pytania o aktualny stan środowiska ekonomistów akademickich, w szczególności w kontekście ich wyborów teoretycznych. Opracowanie jest próbą odpowiedzi, przynajmniej częściowa, na te pytania. Analiza materiału zgromadzonego w trakcie badań empirycznych ${ }^{4}$ pozwoliła na wskazanie do jakich szkół myśli

od powielania wzorów radzieckich, chociaż pozostawała w ramach zakreślonych przez szeroko rozumianą teorię marksistowską.

2 W okresie PRL ekonomia polska wyróżniała się rozważaniami w ramach ekonomii politycznej socjalizmu. Polscy ekonomiści marksistowscy (zwłaszcza O. Lange, W. Brus, A. Wakar czy E. Lipiński) formułowali oryginalne koncepcje zasad funkcjonowania i reform systemu gospodarki centralnie planowanej. Jednak w momencie zwrotu ustrojowo-gospodarczego prace te straciły swój punkt odniesienia i znaczenie.

3 Związane są one $\mathrm{m}$. in. ze wzrostem konkurencji na rynku edukacyjnym i powstaniem prywatnych uczelni ekonomicznych, nie tylko w tradycyjnych ośrodkach akademickich, ale również w miejscowościach nie mających wcześniej doświadczeń na tym obszarze. W konsekwencji, kadra naukowobadawcza rekrutuje się z różnych ośrodków ekonomicznych i często ma odmienne doświadczenia zawodowe, a także przygotowanie metodologiczne. Istotne znaczenie dla funkcjonowania uczelni ma przebieg procesu integracji europejskiej w zakresie szkolnictwa wyższego, toczący się w ramach Procesu Bolońskiego.

4 Badania empiryczne przeprowadzono w latach 2014-2016 w ramach projektu NCN pt. Identyfikacja polskich ekonomistón akademickich ze szkotami myśli ekonomicznej (UMO-2013/09/B/HS4/02706). Projekt realizował zespół w składzie: Grzegorz Konat, Wanda Karpińska-Mizielińska, Kazimierz Kloc, Tadeusz Smuga (kierownictwo). Podstawowe narzędzie badawcze stanowiła ankieta internetowa przeprowadzona w 2015 r. wśród ekonomistów akademickich posiadających co najmniej stopień doktora. Badaniem objęto pracowników naukowych z: wydziałów ekonomicznych wszystkich państwowych uczelni ekonomicznych i uniwersytetów (ogólnych), wydziałów ekonomicznych pięciu celowo dobranych prywatnych uczelni, Instytutu Nauk Ekonomicznych PAN oraz instytutów badawczych statutowo prowadzących badania na obszarze nauk ekonomicznych. W ramach projektu przeprowadzono także wywiady pogłębione (20) z ekonomistami o bardzo wysokiej pozycji naukowej, stanowiącymi autorytety w naukach ekonomicznych, reprezentujących różne ośrodki naukowe [Konat, Smuga, 2016]. 
ekonomicznej ${ }^{5}$ należą polscy ekonomiści akademiccy, a także jakie zmienne o charakterze społecznym (cechy osobowe, edukacja ekonomiczna, przebieg kariery zawodowej) determinuja ich wybory teoretyczne. Podczas realizacji projektu zebrano również wiele interesujących informacji dotyczących poglądów na temat stanu nauk ekonomicznych, barier występujących w rozwoju polskiej ekonomii, a także cech osobowych badanych, co pozwoliło na szerszą charakterystykę tego środowiska naukowego.

\section{Badania nad rolą uczonych}

Refleksja nad rolą uczonych pojawiła się w myśli filozoficznej już w okresie starożytności. Mamy tu na uwadze rozważania filozofów, kreujących obraz idealnego (doskonałego) państwa, przypisującego tej grupie (mędrcom, filozofom) czołową rolę w rządzeniu [Platon, 2010]. Wątek ten pojawia się następnie w twórczości wielu teoretyków ${ }^{6}$. W kontekście analizy tego problemu, szczególnie ważny jest rozwój socjologii wiedzy [Mannheim, 1961]. Bada ona związki między warunkami powstawania wiedzy (nauki) a jej treścią, identyfikuje prawidłowości pojawiania się określonych typów myślenia i analizuje ich kontekst społeczny.

Argumentem na rzecz zainteresowania środowiskiem nauki jako przedmiotem badań jest także bardzo wysoka pozycja uczonych (zwłaszcza profesorów) w hierarchii prestiżu społecznego. Zjawisko to dotyczy wielu społeczeństw, w tym również Polski. Potwierdzają to liczne badania, a także sondaże opinii na temat prestiżu zawodów [Wagner, 2011] .

Pomimo wielu argumentów na rzecz zainteresowania się środowiskiem naukowców jako przedmiotem analiz naukowych, badania - zwłaszcza empiryczne - tej grupy podejmowano bardzo rzadko. Odnosi się to również do środowiska ekonomistów akademickich. Nie oznacza to jednak braku jakiejkolwiek refleksji nad

5 W naukach ekonomicznych mamy do czynienia z różnymi szkołami myśli ekonomicznej, czyli koherentnymi systemami przekonań i poglądów na temat funkcjonowania systemu gospodarczego oraz w kwestii podstawowych założeń dotyczących podmiotu gospodarującego. Zasadniczo wyodrębnia się dwie grupy szkół myśli ekonomicznej: ortodoksyjne (głównego nurtu) oraz heterodoksyjne (nurtów opozycyjnych). Do pierwszej zalicza się przede wszystkim nową ekonomię klasyczną oraz nową ekonomię keynesowską. Do „nowoczesnych szkół heterodoksyjnych należą natomiast: szkoła austriacka, instytucjonaliści, postkeynesiści i radykałowie” [Landreth, Colander, 2005, s. 27]. Należy również pamiętać, że wszystkie te szkoły podlegały wewnętrznym przemianom, wzajemnym wpływom, poszczególni ich przedstawiciele zmieniali swoje poglądy, a w ramach jednego kierunku istniały stanowiska epistemologiczne odmienne.

6 Tematykę roli społecznej uczonych podejmował m. in. Jan Szczepański w swych szkicach dotyczacych roli inteligencji. Zwraca w nich uwagę na wzrost roli uczonych w procesach decyzyjnych. Podkreślał, że współczesny polityk bez ekspertów dysponujących specjalistyczną wiedza jest bezradny, a ,kadry uczonych sa decydującym czynnikiem siły politycznej, ekonomicznej i militarnej państw" [Szczepański, 1973].

7 Należy zauważyć, że społeczna hierarchia prestiżu rozmija się z ocenami własnej pozycji, formułowanymi przez przedstawicieli danego środowiska. Te ostatnie dotyczą hierarchii zawodów opierającej się na kryterium dochodu, a nie prestiżu społecznego. 
tym środowiskiem. W tym kontekście na uwagę zasługują teoretyczne studia metodologów ekonomii, nie odwołujące się do praktyki i nie weryfikujące empirycznie stawianych hipotez na temat świadomości naukowej ekonomistów [Czarny, 2010; Hardt, 2013]. Z drugiej strony, istnieje bogata literatura obejmująca luźne refleksje na temat środowiska naukowego ekonomistów i jego wybranych przedstawicieli [tukawer, 2008; Sadowski, 2011], jak również wywiady z uznanymi badaczami, mające na celu wyrobienie sobie poglądu na współczesną ekonomię na tle ich życiowych doświadczeń i indywidualnych motywacji [Samuelson, Barnett, 2007; Snowdon, Vane, 2003] $]^{8}$.

W polskim dorobku dotychczas brak jest pogłębionych badań empirycznych środowiska ekonomistów, w tym analiz ich postaw na różnych obszarach oraz ocen własnej grupy zawodowej ${ }^{9}$. Badania ankietowe tego typu prowadzono głównie w Stanach Zjednoczonych. Najczęściej obejmowały one członków Amerykańskiego Towarzystwa Ekonomicznego (AEA), ale także przedstawicieli poszczególnych subdyscyplin ekonomii, takich jak historycy gospodarczy [Whaples, 1995], ekonomiści wyboru publicznego [Whaples, Heckelman, 2005], czy też ekonomiści pracy [Whaples, 1996]. Ankietowanych pytano głównie o poglądy polityczne i stanowiska wobec wybranych problemów polityki gospodarczej oraz społecznej, niekiedy także o kwestie natury teoretycznej [Alston i in., 1992; Fuller, Geide-Stevenson, 2003; Klein, Stern, 2006; Whaples, 2006 $]^{10}$.

Studia (chociaż nieliczne) na temat przynależności ekonomistów do szkół myśli ekonomicznej prowadzono natomiast w Europie, m. in. w Niemczech [Frey i in., 2010] oraz we Włoszech [Di Maio, 2013], w których zaobserwowano znaczną odmienność poglądów na temat skuteczności różnych polityk gospodarczych pomiędzy ekonomistami głównego nurtu a reprezentantami szkół heterodoksyjnych ${ }^{11}$.

Analizując sytuację polskich ekonomistów w okresie zmiany systemu społecznoekonomicznego, należy zwrócić uwagę na olbrzymie zapotrzebowanie na nich

8 Nie można również pominać licznych analiz dotyczących kształtowania się myśli ekonomicznej, ujmujących to zagadnienie wyłącznie z perspektywy historycznej. W tym kontekście należy zwrócić uwage na prace analizujące myśl ekonomistów XX wieku, wykorzystujące metodę analizy treści dokumentów, w tym publikacji, zapisów wystąpień publicznych, a także dokumentów o charakterze biograficznym [Grzybek, 2012].

9 Jedyne badania, które przez pewien czas prowadzone były wśród nich cyklicznie, miały charakter sondażu opinii na temat realizowanej przez rząd polityki gospodarczej [Rozwój..., 2014]. Ich celem było zebranie opinii ekonomistów (zarówno naukowców, jak i pracowników instytucji finansowych) na temat konkretnych działań podejmowanych w polityce gospodarczej rządu, ocena jej jakości oraz sformułowanie rekomendacji.

10 Pomiędzy tymi badaniami a prezentowanymi w niniejszym opracowaniu występuje zasadnicza różnica metodologiczna. Dotyczy ona przede wszystkim sposobu doboru ankietowanych. W naszych badaniach analizowana próba była bardziej jednorodna i obejmowała tylko ekonomistów zatrudnionych na uczelniach wyższych oraz w instytutach naukowo-badawczych, posiadających co najmniej stopień doktora.

11 Co więcej, heterodoksyjni ekonomiści nie tylko nie zgadzali się z ekonomistami głównego nurtu, ale opinie na temat gospodarki wewnątrz tej grupy były bardziej zróżnicowane niż w głównym nurcie. Z drugiej strony, podzielali oni wspólny zestaw analitycznych instrumentów, z których zastosowania wynikały ich propozycje w zakresie polityki gospodarczej. 
w pierwszych latach transformacji. Wynikało to przede wszystkim z poszukiwania kadr (o wysokich kompetencjach) zdolnych do przeprowadzania reform. W tej sytuacji rola ekonomistów w pierwszych latach transformacji systemowej, w tym również w procesach decyzyjnych, istotnie wzrosła. Chodzi tu w szczególności o bezpośrednie uczestnictwo w tych procesach (np. zajmowanie wysokich stanowisk w organach administracji publicznej), jak i pośrednie, poprzez pełnienie funkcji ekspertów biorących udział w przygotowaniu decyzji [Raciborski, 2006].

\section{Kogo badaliśmy? Cechy osobowe ekonomistów}

W badaniach zwróciliśmy szczególną uwagę na społeczne cechy ekonomistów ${ }^{12}$. Objęta nimi grupa była znacznie zróżnicowana ze względu na cechy osobowe, przede wszystkim wiek, a co za tym idzie posiadane doświadczenia zawodowe. Wyróżniono dwie, istotne w kontekście dalszej analizy, grupy ekonomistów. Pierwsza zdobywała wykształcenie akademickie przed rozpoczęciem transformacji systemowej (ekonomiści tej grupy w momencie badania mieli powyżej 50 lat), druga natomiast (w wieku poniżej 50 lat) w okresie zmiany systemowej.

Wśród badanych (przy pomocy ankiety) przeważali mężczyźni $(61,5 \%)^{13}$. Udział kobiet wynosił 38,5\% (20,0\% - w wywiadzie), co w znacznym stopniu odzwierciedla strukturę naukowców w Polsce ze względu na płeć [Siemieńska, 2003]. Na ankietę odpowiedziały przede wszystkim osoby stosunkowo młode, większość nie przekroczyła 45 lat $(58,9 \%)$, a więc należące do drugiej z wyróżnionych przez nas grup respondentów. Struktura badanych ze względu na wiek w ankiecie była więc zasadniczo odmienna niż w przypadku badanych metodą wywiadu otwartego, wśród których przeważali ekonomiści powyżej 60 lat. Wykształcenie i doświadczenia zawodowe zdobywali więc w poprzednim systemie społeczno-ekonomicznym. W tej sytuacji badane obu metodami zbiorowości ekonomistów znacząco różniły się, przede wszystkim pozycją zawodową oraz doświadczeniami życiowymi, co niewątpliwie mogło mieć istotny wpływ na dokonywane przez nich wybory ekonomiczne, a także formułowane w wypowiedziach poglądy.

Dane ankiety wskazują znaczące różnice udziału kobiet w dwu krańcowych przedziałach wiekowych, wśród najmłodszych (do 35 lat) było ich ponad pięciokrotnie więcej niż w grupie powyżej 65 lat $(23,5 \%$ wobec $4,2 \%)$. Wskazuje to na istotne zmiany zachodzące $\mathrm{w}$ strukturze według płci wśród ekonomistów wcho-

12 Na kwestię społecznych uwarunkowań wiedzy (jej powstawania, przetwarzania i upowszechniania) zwrócił uwagę Karl Mannheim - twórca klasycznej socjologii wiedzy [Mannheim, 1961].

$13 \mathrm{Na}$ adresy mailowe ponad 3000 naukowców akademickich wysłano informację o celach badania wraz z zaproszeniem do udziału w nim. Ankieta była dostępna w Internecie od 19 czerwca do 20 sierpnia 2015 r. Miały z nią kontakt 1293 osoby, natomiast zwrócono 309 wypełnionych ankiet (10,1\% populacji, do której wysłano maile oraz $23,9 \%$ tych, którzy mieli kontakt $z$ ankietą na stronie internetowej). 
dzących w życie zawodowe w okresie transformacji. Wyrażają się one wzrostem udziału kobiet podejmujących pracę naukowa.

Ważną zmienną determinująca zachowania i wybory życiowe badanych jest środowisko społeczne, z jakiego się rekrutuja. Badani pochodzili przede wszystkim ze środowisk o stosunkowo wysokim cenzusie wykształcenia (wyższe wykształcenie rodziców), a także z dużych lub średnich miast. Te dwa elementy składające się na środowisko w jakim wychowywali się, pozwoliły im na zdobycie kapitału społecznego użytecznego na kolejnych etapach kształcenia, i dalej - kariery zawodowej. Potwierdza to więc przypuszczenia o dziedziczeniu wykształcenia, a więc i pozycji społecznej. Tylko $1 / 10$ badanych ekonomistów wychowała się na wsi, a $1 / 5$ pochodziła z rodzin, w których rodzice mieli tylko wykształcenie podstawowe.

Badana populacja była jednorodna pod względem miejsca uzyskania dyplomu studiów wyższych, jak również profilu studiów. Wykształcenie magisterskie (najczęściej na kierunku ekonomia - 70,7\% ${ }^{14}$ zdobywano na polskich uczelniach publicznych $(94,5 \%)$. Tylko w nielicznych przypadkach - na uczelniach zagranicznych lub krajowych niepublicznych (odpowiednio 3,2 i 2,3\%). Brak istotnych zróżnicowań obserwujemy również w strukturze zatrudnienia ekonomistów - około $89 \%$ pracowało w uczelniach publicznych, a tylko około $11,0 \%$ - w uczelniach prywatnych.

Największy udział w badanej próbie mieli respondenci ze stopniem doktora $52,4 \%$, (co wiąże się ze strukturą według wieku). Licznie reprezentowani byli również profesorowie $(30,1 \%)$. Badanych natomiast znacznie zróżnicował obszar zainteresowań naukowych (pól badawczych) ${ }^{15}$. Zaobserwowano wśród nich koncentrację na kilku obszarach: a) rozwoju gospodarczym, innowacjach, postępie technologicznym i wzroście, b) metodach matematycznych i ilościowych, c) zarządzaniu i ekonomii menedżerskiej, marketingu i rachunkowości, d) makroekonomii i ekonomii monetarnej oraz e) mikroekonomii.

Znaczna część ekonomistów akademickich miała bezpośrednie kontakty z ekonomią światową. Blisko połowa $z$ nich przebywała na co najmniej trzymiesięcznych stażach lub stypendiach zagranicznych. Najczęściej byli to respondenci z dwóch grup wiekowych: 36-45 lat (28,4\%), a następne powyżej 65 lat (21,6\%).

Przeciętny, objęty badaniem ankietowym ekonomista, był więc mężczyzna, w wieku do 45 lat, miał tytuł doktora nauk ekonomicznych, pochodził z dużego lub średniego miasta, z rodziny o wyższym wykształceniu (najczęściej obojga) rodziców. Studia magisterskie ukończył na krajowej uczelni publicznej, najczęściej na kierunku ekonomia i z tym typem uczelni zwiazzany był pracą zawodową.

Trochę więcej danych dotyczących indywidualnych doświadczeń, w tym również motywacji przy wyborze zawodu i drogi kariery naukowej uzyskaliśmy podczas wy-

14 Część respondentów dyplom magistra zdobywała na innych kierunkach, jak: zarządzanie, finanse i nauki społeczne (odpowiednio 14,9\%, 8,0\% i 8,0\%), natomiast kierunki z obszaru nauk ścisłych ukończyło $5,8 \%$, technicznych $-4,9 \%$, a przyrodniczych $-2,6 \%$.

15 W pytaniu o pole badawcze respondentów wykorzystano klasyfikację JEL [Karbownik, Knauff, 2010]. Respondenci nie byli w nim ograniczeni liczbą odpowiedzi, mogli zaznaczyć dowolną liczbę obszarów zainteresowań. 
wiadów ze znanymi ekonomistami. Objęto nimi wprawdzie grupę zróżnicowaną wiekowo, rozpiętość wieku (pomiędzy najstarszym a najmłodszym z badanych) wynosiła 35 lat, ale uwzględniając kategorie wieku wyodrębnione w ankiecie musimy pamiętać, że wszyscy badani objęci wywiadami należeli do dwóch najstarszych przedziałów wieku - a więc mieli powyżej 56 lat ${ }^{16}$.

Dla większości z nich ekonomia była pierwszym, z reguły świadomie wybranym kierunkiem studiów. O jej wyborze na ogół decydowały wcześniejsze (z okresu liceum) zainteresowania ogólne, w tym ekonomią i problematyką społeczną. Badanych wyróżniał wysoki poziom indywidualnych motywacji i osobistych ambicji, który sprzyjał rozwojowi dalszej kariery zawodowej. Łączyło ich także wiele wspólnych elementów biografii, dróg osiagania pozycji naukowej, a przede wszystkim doświadczeń - związanych ze zdobywaniem wykształcenia i osiaganiem pozycji zawodowej w poprzednim systemie politycznym - w socjalizmie. Stąd w niektórych wypowiedziach nawiązywano do tych kwestii, podkreślano np., że pomimo tego, że kształcenie ekonomistów było w tym okresie podporządkowane ideologii, to już w czasie studiów zetknęli się szerzej, w sposób bardziej pogłębiony, z ekonomię zachodnią. Szczególną rolę w ukształtowaniu ich zainteresowań odegrało środowisko naukowe $\mathrm{z}$ okresu studiów lub bezpośrednio po nich, osobisty kontakt $z$ wybitnymi naukowcami, m. in. M. Kaleckim i O. Lange. Doświadczenia te stanowiły ogromny kapitał społeczny przyśpieszający ich własne kariery naukowe.

Zebrany materiał wskazuje jak ogromna rolę w kształtowaniu młodych naukowców odgrywają autorytety. Potwierdzają to dane z wywiadów. Wielu z respondentów na pierwszym etapie swojego życia zawodowego miało jakieś osoby w środowisku akademickim, które odegrały istotną rolę w ukształtowaniu ich osobowości i przygotowaniu do wypełniania przyszłych ról uczonych, a także skłoniły do zainteresowania się pracą naukowa (a nawet konkretną problematyką badawcza). W wypowiedziach na temat indywidualnych inspiracji $\mathrm{i}$ autorytetów wymieniano przede wszystkim M. Kaleckiego, O. Langego, A. Wakara oraz Z. Sadowskiego.

Większość z badanych już w tym okresie nawiązała liczne kontakty zagraniczne, na ogół podczas odbywania stypendiów i staży zagranicznych. Wyjazdy zagraniczne pełniły istotną rolę $\mathrm{w}$ zdobyciu (poprawie) indywidualnej pozycji zawodowej, poznaniu warsztatu i metod pracy, umożliwiły ponadto bezpośredni kontakt z wybitnymi ekonomistami o randze światowej.

\section{Wybory teoretyczne}

Analizy przynależności ekonomistów do szkół myśli ekonomicznej prowadzone w Europie pozwoliły na pogłębienie wiedzy na temat ich poglądów. Ekonomiści niemiecko języczni [Frey i in., 2010] w większości określili się jako zwolennicy szkoły neoklasycznej. Zaobserwowano wśród nich dużą otwartość na nurty nieorto-

16 Większość (10) urodziła się w okresie wojny i w ciagu pierwszych pięciu lat powojennych, 3 osoby przed II wojną światowa, a $7 \mathrm{w}$ latach pięćdziesiątych XX wieku. 
doksyjne. Z kolei w badaniu przeprowadzonym we Włoszech wśród pracujących na wyższych uczelniach, największa grupa określiła się jako eklektycy (28\%) [Di Maio, 2013; De Benedictis, Di Maio, 2011; De Benedictis, Di Maio, 2014] ${ }^{17}$. Licznie reprezentowani byli także neoklasycy (18\%), a także odwołujący się do myśli Johna Maynarda Keynesa (19\%). Szkołę instytucjonalna/neoinstytucjonalną wymieniło 7\% respondentów, ewolucyjną - 5\%, a marksistowska/neomarksistowska $-4 \%$. Minimalne wskazania - na poziomie 1\% lub poniżej - dotyczyły szkoły behawioralnej i austriackiej/neoaustriackiej.

TABELA 1

\section{Szkoły dominujące w polskiej ekonomii oraz szkoły z którymi identyfikowano się}

\begin{tabular}{|l|c|c|}
\hline \multicolumn{1}{|c|}{ Wyszczególnienie } & $\begin{array}{c}\text { Szkoła z którą się } \\
\text { identyfikowano }\end{array}$ & $\begin{array}{c}\text { Szkoły dominujące } \\
\text { w polskiej ekonomii }\end{array}$ \\
\hline ekonomia neoaustriacka & 8,1 & 3,9 \\
\hline ekonomia radykalna & 2,6 & 0,6 \\
\hline nowa ekonomia instytucjonalna & 30,4 & 14,6 \\
\hline nowa ekonomia keynesowska & 12,9 & 15,2 \\
\hline nowa ekonomia klasyczna & 15,2 & 20,4 \\
\hline postkeynesizm & 4,2 & 4,5 \\
\hline eklektyzm & 16,8 & 35,6 \\
\hline inne & 9,7 & 5,2 \\
\hline
\end{tabular}

Źródło: opracowanie własne na podstawie wyników badań ankietowych.

Rozkład odpowiedzi polskich ekonomistów akademickich na temat identyfikacji ze szkołami myśli ekonomicznej znacznie odbiega od tych, obserwowanych w cytowanych wyżej badaniach (tabela 1). Wynika to niewatpliwie $z$ odmiennych doświadczeń historycznych, a także stopnia włączenia się polskiej ekonomii w naukę światową. Wśród badanych zdecydowanie przeważali deklarujący swój związek z nowa ekonomia instytucjonalną (30,4\%). Blisko dwukrotnie mniejszą liczbą wskazań uzyskały: eklektyzm, nowa ekonomia klasyczna oraz nowa ekonomia keynesowska (odpowiednio: 16,8\%; 15,2\% i 12,9\%). Na uwagę zasługuje również fakt, że odsetek ankietowanych, którzy określili się jako neoaustriacy $(8,1 \%)$ był wyższy od udziału ekonomistów postkeynesowskich i radykalnych (łącznie 6,8\%).

17 Dokonane przez respondentów wybory szkół autorzy badania zagregowali do dwóch grup: nurt główny i nurt heterodoksyjny. Wykazano w nim, że ekonomiści głównego nurtu i heterodoksyjni mieli zasadniczo odmienne poglądy na temat skuteczności różnych polityk gospodarczych. Co więcej, heterodoksyjni ekonomiści nie tylko nie zgadzali się z ekonomistami głównego nurtu, ale opinie na temat gospodarki wewnątrz tej grupy były bardziej zróżnicowane niż w głównym nurcie. Z drugiej strony, podzielali oni wspólny zestaw analitycznych instrumentów, z których wynikały formułowane przez nich propozycje w zakresie polityki gospodarczej. 
Grupując szkoły myśli ekonomicznej na ortodoksyjne i heterodoksyjne okazuje się, że blisko połowa badanych $(45,3 \%)$ czuła się związana z nurtami heterodoksyjnymi, a niewiele ponad $1 / 4(28,1 \%)$ ze szkołami zaliczanymi do ortodoksji. Pozostali ekonomiści wybrali eklektyzm lub inne szkoły. Należy jednak pamiętać, że podział na poszczególne szkoły obecne w polskiej ekonomii akademickiej jest nieostry, między innymi ze względu na fakt, iż wielu ekonomistów w swojej pracy mniej lub bardziej świadomie - łączy elementy różnych nurtów. To samo może dotyczyć całych szkół, czego najlepszy przykład stanowi eklektyczna szkoła określana jako „nowa ekonomia instytucjonalna” [Godłów-Legiędź, 2010].

W kontekście tematu opracowania szczególnie istotny jest bardzo niewielki odsetek wskazań na ekonomię radykalną (2,6\%). Jeszcze mniejsza grupa uznała nurty wywodzace się z marksizmu za dominujące obecnie w polskiej ekonomii (zaledwie $0,6 \%$ ). W praktyce więc prawie wszyscy badani odrzucili marksizm, przynajmniej w swych deklaracjach. Sygnalizuje to także, że szeroka akceptacja dla tej szkoły w okresie poprzedzającym transformację systemowa miała raczej charakter powierzchowny (na pokaz) i nie wiązała się z rzeczywistym podzielaniem poglądów ją konstytuujących. Potwierdza tezę o ideowym zwrocie jaki dokonał się w okresie transformacji systemowej wśród polskich ekonomistów akademickich. Zaobserwowana w badaniu słabość nurtów lewicowych wiąże się także z klimatem politycznym i ideologicznym (który znalazł również swoje odzwierciedlenie w programach nauczania ekonomii w szkołach wyższych) dominującym w Polsce po 1989 r., w pierwszych latach transformacji systemowej. Jego symptomem była nie tylko euforia dla wprowadzanych zmian systemowych, ale także odrzucanie poglądów (zwłaszcza gospodarczych) uznawanych za „lewicowe”. W konsekwencji środek ciężkości dyskusji ekonomicznych uległ przesunięciu „w prawo”, w kierunku skrajnego liberalizmu.

Wśród nurtów heterodoksyjnych przeważała nowa ekonomia instytucjonalna i szkoła austriacka. Obie te szkoły są heterodoksyjne, ale jednocześnie we wspó1czesnym wydaniu zbliżone do założeń nurtu głównego. W dużym stopniu afirmują one wolny rynek (szkoła neoaustriacka) lub nie podważaja założeń wolnorynkowych teorii lecz jedynie je uzupełniaja (nowa ekonomia instytucjonalna). Szkoły te stały się modne szczególnie po kryzysach finansowych początku XXI wieku, w wyniku których podejście „czysto” ortodoksyjne stało się mniej popularne.

Godny uwagi jest także wysoki udział wśród polskich ekonomistów osób określających się jako eklektycy $(16,8 \%)$. Nie jest wprawdzie tak wysoki, jak w cytowanym badaniu przeprowadzonym we Włoszech, ale również i w Polsce pozycja eklektyzmu jest znacząca (druga ze względu na liczbę wskazań). Jego wybór stanowił niewątpliwie wygodny sposób odpowiedzi na pytanie o samoidentyfikację dla tych, którzy koncentrowali się na analizie szczegółowych kwestii ekonomicznych i w mniejszym stopniu interesowali się zagadnieniami teoretycznymi, ale także dla tych, którzy chcieli uniknąć wskazania określonej szkoły myśli ekonomicznej. Nie możemy również wykluczyć, że wśród eklektyków znaleźli się ekonomiści sympatyzujący z podejściem radykalnym, którzy nie chcieli przyznawać się do swoich poglądów, zwłaszcza w obliczu ostrej krytyki poglądów rozbieżnych ze światopoglądem 
liberalnym. Obserwacje te w części potwierdza rozkład odpowiedzi na pytanie o szkoły dominujące w polskiej ekonomii akademickiej (tabela 1). Większość respondentów wskazała właśnie silną pozycję eklektyzmu i była przekonana, że mamy do czynienia raczej z łączeniem poglądów różnych szkół niż z jednym, spójnym systemem myślenia $(35,6 \%)^{18}$.

Pytanie o identyfikację ze szkołami myśli ekonomicznej, jak również o szkoły dominujące w polskiej ekonomii zadaliśmy również uczestnikom wywiadów. Część z nich unikała wprawdzie odpowiedzi wprost na to pytanie, twierdząc, że "niewiele osób w Polsce utożsamia się z jakąś szkołą" lub mamy do czynienia z próbami syntetyzowania elementów różnych szkół, np. ekonomii nowego keynesizmu z elementami nowej ekonomii instytucjonalnej. Wśród badanych zdecydowanie przeważało odwoływanie się do tradycji keynesistowskich. Reprezentowane wśród nich były także inne nurty teoretyczne, jak instytucjonalizm, neoliberalizm, szkoła neoaustriacka oraz nowa ekonomia klasyczna.

Szczegółowa analiza poglądów merytorycznych ekonomistów (zebranych w badaniu ankietowym) pokazała, że zarówno ich wiedza na temat treści poszczególnych szkól, jak i własne poglądy ekonomiczne zasadniczo odbiegały od teoretycznych założeń szkół, z którymi się identyfikowali. I tak np. zdecydowana większość badanych $(73,5 \%)$ aprobowała pogląd o dopuszczalności interwencji państwa w gospodarce, charakterystyczny dla keynesowskich szkół myśli ekonomicznej. Nowi instytucjonaliści na przykład częściej wskazywali na kategorię nowokeynesowską niż nowoinstytucjonalna. Interwencjonizm dopuszczali również nowi klasycy, a nawet neoaustriacy, wśród których bez mała jedna trzecia wskazała na jego dopuszczalność w pewnych (chociaż ograniczonych) warunkach. Liczne wskazania reprezentantów tak różnych szkół na znaczenie interwencji państwa pozwalają wnioskować, iż wybory te nie były przypadkowe i stanowiły odzwierciedlenie poglądów faktycznie podzielanych przez polskich ekonomistów [Karpińska-Mizielińska, Smuga, 2017]. Największy udział zwolenników interwencji państwa wystąpił w dwóch kategoriach wiekowych - powyżej 65 lat $(89,2 \%)$ i 46-55 lat $(87,2 \%)$, zaś wyraźnie mniejszy - do 35 lat $(74,5 \%)$ i 56-65 lat (76,7\%). Pomimo różnic w ocenach dopuszczalności interwencjonizmu, podobne tendencje w formułowanych na jego temat opiniach obserwowaliśmy wśród uczestników wywiadów. Nikt nie znalazł się wśród nich kto by całkowicie negowal potrzebę takiej interwencji. Potwierdza to jeden z badanych, który zauważył: „dzisiaj jest mało ekonomistów, którzy by negowali jakąkolwiek rolę państwa, chociaż występują różnice w ocenach skali interwencji państwa, stopnia ingerencji w procesy gospodarcze".

Podobne zjawiska w poglądach ekonomistów obserwowaliśmy również w przypadku odpowiedzi na inne pytania. W odniesieniu do źródeł niestabilności gospodarki kapitalistycznej przeważało stanowisko nowej ekonomii instytucjonalnej, a w kwestii równowagi gospodarki kapitalistycznej przekonanie o jej braku (ekonomia radykalna). Były to najbardziej rozpowszechnione poglądy, o których możemy

18 Znacząca pozycję przypisano ponadto trzem szkołom: nowej ekonomii klasycznej, nowej ekonomii keynesowskiej oraz nowej ekonomii instytucjonalnej (odpowiednio: 20,4\%;15,2\%; 14,6\%). 
mówić jako elementach swego rodzaju konsensusu wśród polskich ekonomistów akademickich. Świadczą one również o faktycznym eklektyzmie poglądów.

Przeprowadzone badania ujawniły stosunkowo niewielką spójność poglądów ekonomistów akademickich w kwestiach merytorycznych. Prezentowali oni dość zróżnicowane poglądy, odbiegające niekiedy zasadniczo od teoretycznych założeń szkół, do których według własnych deklaracji należą. Taki stan rzeczy może wynikać ze świadomego eklektyzmu panującego w polskiej (a może również światowej) ekonomii, którego skutkiem są zróżnicowane poglądy na wiele kwestii, jak i z niewystarczającego przygotowania teoretycznego a w konsekwencji dość przypadkowego przypisywania swoich poglądów danej szkole. Pożądana w związku z tym byłaby analiza programów nauczania ekonomii na uczelniach ekonomicznych w Polsce, w szczególności w kontekście obecności w nich przedmiotów z zakresu teorii ekonomii, historii myśli ekonomicznej oraz metodologii badań ekonomicznych.

\section{Poglądy na temat rozwiązań w polityce gospodarczej}

Analiza odpowiedzi respondentów na pytanie o najważniejsze problemy, których rozwiązanie jest warunkiem zapewnienia dynamicznego rozwoju polskiej gospodarki, pozwala na charakterystykę ich poglądów na temat pożądanych kierunków interwencji publicznej. Dostarcza również informacji na temat postaw i podzielanych wartości (np. lewicowe, liberalne bądź konserwatywne).

Badani największe znaczenie przypisywali rozwiązaniu problemu niesprawności instytucji publicznych, a następnie niewydolności systemu prawa (odpowiednio 60\% i 48\%). Kolejne, licznie wskazywane problemy, to: duże obciązenie kosztów pracy, niska innowacyjność gospodarki (odpowiednio: 39\% i 38\%), a następnie (blisko 1/3 wskazań), przerost biurokracji, duże nierówności społeczne oraz przywileje niektórych grup zawodowych. Wśród najrzadziej wymienianych problemów znalazły się: niedostateczne ułatwienia dla inwestycji zagranicznych, zbyt niski poziom bezpieczeństwa energetycznego, zbyt mały zakres państwa opiekuńczego, zbyt silna pozycja związków zawodowych oraz wysoki stopień zanieczyszczenia środowiska. Według badanych, dynamiczny rozwój Polski wymaga przede wszystkim głębokich zmian w funkcjonowaniu instytucji państwa, gdyż tworzą one warunki prawne i instytucjonalne sprawnej gospodarki.

W przypadku wskazań na wiele z tych problemów nie zaobserwowaliśmy istotnych różnic pomiędzy kobietami a mężczyznami. Dotyczyło to np: obciążenia kosztów pracy, przerostu biurokracji, wsparcia kapitału krajowego, możliwości awansu społecznego, poziomu bezpieczeństwa energetycznego czy też wydolności systemu prawa. Różnice pojawiły się natomiast w przypadku oceny znaczenia problemu nierówności społecznych, przywilejów niektórych grup zawodowych, a także zbyt małej skali państwa opiekuńczego. Kobiety wskazywały na te problemy częściej. Mężczyźni natomiast, częściej niż kobiety, mówili o niskiej innowacyjności gospodarki, opóźnieniach we wstapieniu do strefy euro, ograniczonej suwerenności polskiej gospodarki, zapaści demograficznej oraz zbyt niskim udziale płac w PKB. 
Różnice te można wyjaśniać przede wszystkim indywidualnymi postawami badanych, a także podzielanymi przez nich wartościami, w tym wrażliwością na problemy o charakterze społecznym.

W analizie zebranego materiału kategorie pytania podzielono na trzy grupy: probiznesowe, propracownicze i obojętne. Okazało się, że grupy wiekowe - najmłodsza (do 35 lat) i najstarsza (powyżej 65 lat) były nastawione bardziej propracowniczo, a grupy pośrednie - bardziej probiznesowo (najwyższy udział w grupach 36-45 lat).

W kontekście dalszego rozwoju polskiej ekonomii akademickiej szczególną uwagę zwrócić należy na poglądy respondentów w grupie wieku 36-45 lat, gdyż w następnych latach będą oni $\mathrm{w}$ decydującym stopniu wpływać na treści przekazywane $\mathrm{w}$ ramach nauczania ekonomii na wyższych uczelniach. Respondenci z tej grupy rozpoczynali studia i podejmowali pracę na uczelni na początku okresu transformacji i pierwszych dziesięciu latach przemian ustroju gospodarczego oraz dokonujących się równolegle przekształceń na uczelniach oraz $\mathrm{w}$ nauczaniu ekonomii w oparciu o nurt główny (ekonomia neoklasyczna, keynesizm itd.), a więc w okresie szerokiego entuzjazmu dla gospodarki rynkowej oraz nurtu głównego w ekonomii. Dokonywane przez nich wybory merytoryczne odbiegają więc istotnie zarówno od starszych jak i najmłodszych w badaniu kategorii wieku. Oczekiwać w związku z tym należy, że w kwestiach preferowanych rozwiązań polityki gospodarczej przeważać będa poglądy konserwatywne i orientacja probiznesowa a nie prospołeczna. Wskazuje to na utrwalenie się przewagi orientacji liberalnej w polskiej ekonomii w najbliższych latach ${ }^{19}$.

\section{Uczestnictwo w procesach podejmowania decyzji}

W okresie transformacji systemowej na szczególną uwagę zasługuje istotny wzrost znaczenia ekonomistów w procesach decyzyjnych. Chodzi tu zarówno o zajmowanie przez nich wysokich stanowisk w organach administracji publicznej, jak i pełnienie funkcji ekspertów (doradców) uczestniczaccych w procesach przygotowania decyzji. Szczególne zainteresowanie środowiskiem naukowców uzasadnia również znaczący ich udział w składzie ekip rządowych. Analiza biografii członków rządu w latach 1997-2004 wykazała, że 33\% z nich miało wykształcenie ekonomiczne [Raciborski, 2006].

Podejmowanie przez część naukowców aktywności politycznej nie jest specyficzną cechą środowiska ekonomistów, odnosi się także do przedstawicieli in-

19 Zupełnie inaczej rozłożyły się wybory szkół wśród respondentów z najstarszej grupy wiekowej powyżej 65 lat (12\% badanej populacji). Wyglądały one następująco: instytucjonalna - 35\%; keynesowska, klasyczna, postkeynesowska - każda po 10\%; austriacka - 5\%; eklektyzm - 19\%. Najstarszą grupę wiekową charakteryzowało więc prawie dwukrotnie niższe poparcie dla ekonomii klasycznej i austriackiej niż wśród ekonomistów w przedziale wieku 36-45 lat. Z kolei zwolenników instytucjonalizmu było wśród nich prawie dwa razy więcej. 
nych nauk społecznych, przede wszystkim reprezentantów tych specjalności, które dostarczają wiedzy dającej się stosunkowo łatwo wykorzystać w praktyce politycznej. Szczególnie istotny natomiast wydaje się fakt angażowania w działalność polityczną osób o bardzo wysokiej pozycji w środowisku naukowym. We wspomnianych wyżej badaniach blisko $40 \%$ członków elity rządowej legitymowało się stopniem doktora, doktora habilitowanego lub tytułem profesora ${ }^{20}$.

Potwierdzaja to również wnioski $\mathrm{z}$ naszych badań. Ponad połowa badanych $(55,7 \%)$ w latach 1990-2014 była zatrudniona w innych (poza uczelnia) instytucjach. Trochę częściej dotyczyło to mężczyzn niż kobiet (57,4\% wobec 52,4\%). Najliczniej zatrudniani byli w przedsiębiorstwach $(21,4 \%)$ oraz instytucjach administracji centralnej $(20,4 \%)$, a następnie, chociaż dwukrotnie rzadziej, w podmiotach sektora finansowego oraz organizacjach pozarządowych (po 11,7\%).

Wśród badanych zaobserwowano skłonność do postrzegania działalności publicznej jako przedłużenie działalności naukowej - i traktowania jej jako przestrzeni do praktycznej realizacji swej wiedzy. Oznacza to względną nieświadomość politycznego charakteru ustaleń własnej dyscypliny. Wyrażano bowiem przekonanie, że pełnienie funkcji publicznych nie oznacza uprawiania polityki. Jako osobiste motywacje wymieniano przede wszystkim chęć uczestnictwa w zmianach. Stwierdzano np. że „mieli wielkie szczęście mając możliwość konfrontowania swojej wiedzy makroekonomicznej z polityką gospodarczą i możliwość aktywnego uczestniczenia w podejmowaniu decyzji i ważnych debatach". W ich ocenie dużą rolę w procesie decyzyjnym odegrali jednak tylko ci ekonomiści, którzy byli członkami rządu i mieli szerokie uprawnienia decyzyjne. Wśród objętych wywiadami ekonomistów 1/3 zajmowała wysokie pozycje w administracji rządowej.

Bez watpienia uczestnictwo $w$ procesach decyzyjnych wymagało od nich pewnego kompromisu, pragmatyzmu i umiejętności dostosowania swoich poglądów do istniejących warunków i oczekiwań rządzącego obozu władzy. Jeden z badanych, który takie role wypełniał, zauważył: „zdarzali się ministrowie związani z lewica, bo to zawsze ze środowiska politycznego musi wyjść propozycja takiego stanowiska i bardziej konserwatywni, ale jak obejmowali stanowisko to trudno było później dostrzec różnice pomiędzy nimi. Zwykle decydowały praktyczne wymagania, które nie mają ideologicznego charakteru lecz wynikają z potrzeb. Szybko więc trzeba nauczyć się pragmatyzmu".

Umiejętność wykorzystania wiedzy zewnętrznej poprzez angażowanie specjalistów w proces decyzyjny (ekspertów) należy do istotnych umiejętności kierowniczych. Udział naukowców o wysokich kompetencjach zawodowych powinien być więc pożądany na etapie przygotowywania decyzji. Ich wkład pozwala na ograniczenie ryzyka błędów i poszerza bazę informacyjną decydentów. Zadaniem eksper-

20 Sytuacja w tym zakresie uległa zmianie w obecnej ekipie rządowej, a skala angażowania naukowców była znacznie niższa. W czerwcu 2018 r. w składzie rządu Premiera Morawieckiego [zbiór 101 osób obejmujący premiera, wicepremierów (3), ministrów (18) i wiceministrów (79)] 12,9\% miało wykształcenie ekonomiczne, 17,8\% posiadało tytuł naukowy (od stopnia doktora wzwyż), w tym 2 osoby $(2,0 \%)$ w dziedzinie nauk ekonomicznych. 
tów jest wnoszenie wiedzy obiektywnej (często naukowej), krytycyzmu i niezależności myślenia. W związku z tym naturalne jest, że funkcje doradców powierza się osobom stanowiącym uznane autorytety naukowe, zwłaszcza akademickie. Wśród badanych dominowało przekonanie, że członkowie rządu traktuja przygotowywane przez nich ekspertyzy jako mało przydatne, przywiązują do nich mała wagę i bardzo rzadko z nich korzystaja.

Badani w swych wypowiedziach dostrzegali jednak duże różnice pomiędzy rolami społecznymi polityków i ekspertów. Podkreślano, że „polityk bierze na siebie odpowiedzialność za decyzje, a doradca ma komfortową sytuację - nie ponosi odpowiedzialności. Dobry premier, dobry minister nie ekonomista, jak sam nie potrafi tego zrobić - powinien zamówić ekspertyzę u różnych ekonomistów. Doradca musi być doradca, a nie tym, kto podejmuje decyzje. Decyzje natomiast każdy podejmuje na własny rachunek i nie może powiedzieć, że „tak mi doradzili’””.

\section{Ocena kondycji polskiej ekonomii akademickiej}

Badani ekonomiści bardzo krytycznie wypowiadali się na temat twórczego wkładu polskich nauk ekonomicznych do ekonomii światowej21. Byli przekonani $\mathrm{o}$ istnieniu wielu barier ich rozwoju. Wśród nich największe znaczenie miały te o charakterze zewnętrznym, przede wszystkim finansowe, związane z niewystarczającymi nakładami na naukę w budżecie państwa oraz systemem przyznawania grantów i środków na badania naukowe ( $42 \%$ i 36\% wskazań). Istotną rolę przypisywano również barierom wewnętrznym, związanym ze strukturą i funkcjonowaniem (także polityka) uczelni wyższych. Znalazły się wśród nich - niewystarczająca współpraca $z$ wiodącymi ośrodkami naukowymi na świecie oraz niski poziom merytoryczny kadr naukowych.

Ocena kondycji polskiej ekonomii akademickiej stanowiła również ważny wątek wypowiedzi uzyskanych podczas wywiadów. Większość respondentów dostrzegała pozytywne zmiany, jakie miały miejsce w okresie transformacji. Wspólnym ich mianownikiem był przede wszystkim większy dostęp do międzynarodowych badań naukowych. Wyrażano też przekonanie, że prowadzone w wielu polskich ośrodkach naukowych badania sa zgodne ze standardami zachodnimi. Stawiano sobie przy tym jednak pytanie, czy polska ekonomia wnosi obecnie coś istotnego do ekonomii światowej? Jej pozycję w świecie określano jako daleką od oczekiwań i niesatysfakcjonująca. Zaistnienie w świecie uznano za największy problem do rozwiązania dla polskiej ekonomii akademickiej.

Zwracano uwagę, że w okresie transformacji nie było w Polsce dobrej atmosfery dla wzbogacenia teorii, a w polskiej ekonomii przede wszystkim brakuje ekonomistów podejmujących na arenie międzynarodowej problemy fundamentalne, teoretyczne, a więc takie, które przyczyniałyby się do wzmocnienia jej pozycji w świecie.

21 Blisko 55\% określiło go jako „mały”, 16\% jako „żaden”, 23\% jako „średni”, a zaledwie około 6\% jako „duży” lub „bardzo duży”. 
Oceniano, że zarówno poziom publikacji, jak wielu debat na tematy makroekonomiczne, pozostawia wiele do życzenia. Wśród publikacji w periodykach o znaczeniu światowym dominują artykuły ekonomistów matematycznych, budujących modele ekonomiczne.

Podkreślano, że pochodną niedofinansowania nauki są niskie wynagrodzenia zatrudnionych w szkolnictwie wyższym. Za kluczową kwestię uznano ponadto kształtowanie etosu środowiskowego, mające na celu podniesienie prestiżu (także finansowego) pracy naukowej.

Obowiązujące kryteria oceny jakości pracy uniwersytetu i środowiska naukowego to według badanych kolejna, szczególnie ważna, bariera rozwoju. System ten opiera się na milczącym założeniu, że rezultat pracy naukowej jest mierzalny, a jego ocena może być zobiektywizowana. Wyrażano przekonanie, iż obecny system oceny pracowników naukowo-dydaktycznych wprowadza presję szybkiego publikowania i zdobywania punktów, nie stawia sobie natomiast celu rzeczywistego - wyjaśniania analizowanych zjawisk. Za barierę rozwoju polskiej ekonomii akademickiej uznano również organizację studiów opartą na systemie bolońskim, która negatywnie odbija się na przygotowaniu teoretycznym absolwentów. Z tego względu wskazywano na potrzebę wprowadzenia zmian w sposobie przygotowania ekonomistów do zawodu i rozszerzenia programów studiów o przedmioty z zakresu historii myśli ekonomicznej i metodologii badań. Znakomicie opinie te wyraża pogląd jednego z badanych: „z ubolewaniem stwierdzam, że nastąpiło silne zawężenie profilu kształcenia. Nie wyobrażam sobie dobrego ekonomisty, który nie zna historii myśli ekonomicznej, historii gospodarczej, podstaw socjologii i prawa, który nie ma wiedzy w zakresie metodologii ekonomii i metodologii badań społecznych. Musi mieć także bogatą wiedzę z zakresu matematyki. Świat szybko się zmienia, zmienia się struktura zapotrzebowania na ekonomistów, wasko wyspecjalizowany ekonomista to jest zazwyczaj kiepski ekonomista".

\section{Podsumowanie}

Nie bez znaczenia dla oceny wyników badań dotyczących struktury indywidualnych wyborów teoretycznych ekonomistów są uwarunkowania zewnętrzne, w tym klimat dyskusji publicznych i dominujące w nich poglądy. Polska, budując kapitalizm niemal od podstaw wchodziła $\mathrm{w}$ epokę reform $\mathrm{w}$ okresie całkowitej dominacji neoliberalnej ideologii, stała się swoistym laboratorium jej stosowania. Nie mogło to pozostać bez wpływu na poglądy środowiska naukowego. Potwierdza to tezę Mannheima, że naukowiec jako podmiot poznający nie jest nie uwarunkowanym obserwatorem i badaczem, gdyż rozwój nauki jest zdeterminowany historycznie [Mannheim, 1961].

W kontekście dalszego rozwoju polskiej ekonomii akademickiej, szczególną uwagę zwrócić należy na poglądy ekonomistów w grupie wiekowej 36-45 lat, gdyż w następnych latach będzie ona w decydującym stopniu wpływać na kształt polskiej ekonomii akademickiej i treści przekazywane na wyższych uczelniach. Dokonywane przez nią wybory szkół myśli ekonomicznej wskazują, że nowa ekonomia instytucjo- 
nalna może stracić na znaczeniu, a w kwestiach preferowanych rozwiązań polityki gospodarczej przeważać będą poglądy ortodoksyjnych szkół myśli ekonomicznej.

$\mathrm{W}$ ekonomii zachodniej od połowy XX wieku nastapił bardzo dynamiczny rozwój teorii oraz daleko posunięta segmentacja i profesjonalizacja tej nauki. Oba te procesy zostały w sposób przyspieszony zasymilowane przez polskich ekonomistów akademickich. Proces ten odbył się kosztem osłabienia zainteresowania teoria ekonomii, metodologia badań i historią myśli ekonomicznej. Miało to, co potwierdziły badania, negatywne konsekwencje dla wiedzy ekonomistów i wewnętrznej spójności ich poglądów teoretycznych, a co za tym idzie, pozycję polskiej ekonomii w świecie. Znalazło to wyraz w bardzo krytycznych ocenach dotychczasowego wkładu polskich nauk ekonomicznych do dorobku ekonomii światowej. Świadomość tej sytuacji jest powszechna. Następne dekady pokażą, czy problem ten zostanie przezwyciężony oraz czy polska ekonomia akademicka pozostanie w przeważającym stopniu odzwierciedleniem trendów w ekonomii światowej, czy też wniesie do niej twórczy wkład.

\section{Literatura}

Alston R.M., Kearl J.R., Vaughan M.B., 1992, Is There a Consensus Among Economists in the 1990s?, "American Economic Review", vol. 82(2), pp. 203-209.

Czarny B., 2010, Pozytywizm a sqdy wartościujace w ekonomii, Oficyna Wydawnicza SGH, Warszawa.

De Benedictis L., Di Maio M., 2011, Economists' View About the Economy. Evidence from a Survey of Italian Economists, "Rivista Italiana degli Economisti", vol. 16, pp. 37-84.

De Benedictis L., Di Maio M., 2014, Schools of Thought and Economists' Opinions on Economic Policy, "Eastern Economic Journal", vol. 42, pp. 1-19.

Di Maio M., 2013, Are Mainstream and Heterodox Economists Different? An Empirical Analysis, "American Journal of Economics and Sociology", vol. 72(5), pp. 13151348.

Frey B.S., Humbert S., Schneider F., 2010, What is economics? Attitudes and views of German economists, "Journal of Economic Methodology", vol. 17, no. 3, pp. 317-332.

Fuller D., Geide-Stevenson D., 2003, Consensus Among Economists: Revisited, "Journal of Economic Education”, vol. 34(2), pp. 369-387.

Godłów-Legiędź J., 2010, Współczesna ekonomia. Ku nowemu paradygmatowi?, Wydawnictwo C.H. Beck, Warszawa.

Grzybek D., 2012, Polityczne konsekwencje idei ekonomicznych w myśli polskiej 1869-1939, Księgarnia Akademicka, Kraków.

Hardt L., 2013, Studia z realistycznej filozofii ekonomii, C.H. Beck, Warszawa.

Karbownik K., Knauff M., 2010, Kierunki rozwoju ekonomii na podstawie klasyfikacji Journal of Economic Literature, „Gospodarka Narodowa”, nr 10.

Karpińska-Mizielińska W., Smuga T., 2017, Polscy ekonomiści akademiccy o interwencii państwa w gospodarce, [w:] Państwo a gospodarka, Owsiak S. (red.), PTE Warszawa, s. 76-88. 
Klein B.D., Stern Ch., 2006, Economists policy views and voting, "Public Choice", no. 126, pp. 331-342.

Konat G., Smuga T. (red.), 2016, Paradoksy ekonomii. Rozmowy z.polskimi ekonomistami, PWN SA, Warszawa.

Landreth H., Colander D., 2005, Historia myśli ekonomičnej, Wydawnictwo Naukowe PWN, Warszawa.

Lukawer E., 2008, O tych z najwy ¿̇szej pótki, csyli rzecz w sprawie naszego środowiska ekonomic ₹nego, Polskie Towarzystwo Ekonomiczne, Kraków.

Mannheim K., 1961, Socjologia wiedsy, WSNS, Warszawa.

Platon, 2010, Państwo, PWN, Warszawa.

Raciborski J. (red)., 2006, Elity rzqdowe III RP 1997-2004. Portret socjologiczny, Wydawnictwo Trio, Warszawa.

Rožó́j oraz polityka gospodarcza i społeczna polski, 2014, ogólnopolskie badanie ankietowe opinii ekonomistów, 5 edycja, SGH Warszawa.

Sadowski Z., 2011, Pręez ciekawe czasy. Rozmowy z Pawtem Koztowskim o syciu, ludziach $i$ zdarzeniach, PTE, Warszawa.

Samuelson P.A., Barnett W.A., 2007, Inside the economist mind. Conversation with Eminent Economists, Blackwell Publishing Ltd, USA.

Siemieńska R., 2003, Women In Academe In Poland: winners amongs loosers, Research Raport, Warsaw.

Snowdon B., Vane H.R., 2003, Rozmony z. wybitnymi ekonomistami, Dom Wydawniczy Bellona, Warszawa.

Szczepański J., 1973, Odmiany č̨asu teraźniejszego, Książka i Wiedza, Warszawa.

Wagner I., 2011, Becoming Transnational Professional. Kariery i mobilność polskich elit naukowych, Wydawnictwo Naukowe SCHOLAR, Warszawa.

Whaples R., 1995, Where Is There Consensus Among American Economic Historians? The Results of a Survey on Forty Proposition, "The Journal of Economic History", vol. 55(1), pp. 139-154.

Whaples R., 1996, Is There Consensus among American Labor Economists? Survey Results on Forty Propositions, "Journal of Labor Research", vol. 17(4), pp. 725-734.

Whaples R., 2006, Do Economists Agree on Anything? Yes!, "Economists' Voice", vol. 3(9), pp. 1-6.

Whaples R., Heckelman J.C., 2005, Public Choice Economics: Where Is There Consensus?, "The American Economist", vol. 49(1), pp. 66-78. 